\title{
ВИНИКНЕННЯ МЕБЛЕВОГО ФОРМОТВОРЕННЯ В ДОІСТОРИЧНИЙ ПЕРІОД
}

\begin{abstract}
Мета дослідження - виявлення тенденцій первісного формотворення меблів у доісторичний період. Методологія дослідження - у дослідженні впроваджено метод теоретичного аналізу створення гіпотез на основі відомих фактів із подальшою перевіркою теоретичного припущення новими фактами. Наукова новизна полягає в гіпотетично-обгрунтованому виявленні тенденцій виникнення меблевого формотворення та фактичним підтвердженням його залежності від впливу особливостей природо-кліматичного середовища, антропоморфних розмірів людини, іiі культових уявлень. Висновок. Завдяки гіпотезі доісторичного процесу утворення меблеподібних, а відтак меблевих форм, доведено вплив локальних кліматичних характеристик на побудову еколого-конструктивної схеми меблів. Також зафіксований послідовний вплив на первісне формотворення меблів ергономічного й сакрального чинників; висвітлено залежність первісного формотворення меблів від означеної еколого-конструктивної схеми.

Ключові слова: меблеподібні форми, меблі, генезис, первісне меблеве формотворення, функціональне призначення, типологія меблів.

Стрилец Валерий Федорович, старший преподаватель кафедры технологий и дизайна Киевского национального университета культуры и искусств

Возникновение мебельного формообразования в доисторический период

Цель исследования - выявить тенденции первоначального формообразования мебели в доисторический период. Методология исследования - в исследовании внедрено метод теоретического анализа, создание гипотез на основании извесных фактов, с дальнейшей проверкой теоретического предположения новыми фактами. Научная новизна состоит в гипотетическом выявлении тенденций возникновения мебельного формообразования и фактическим подтвердждением его зависимости от влияния особенностей природо-климатической среды, его антропоморфных размеров, культовых представлений. Вывод. Благодаря гипотезе доисторического процеса образования мебелеподобных, а затем мебельных форм, доказано влияние локальных климатических характеристик на построение эколого-конструктивной схемы мебели. Также зафиксировано последовательное влияние на первоначальное формообразование мебели эргономичного и сакрального факторов, выяснено зависимость первобытного формообразования мебели от этой экологоконструктивной схемы.
\end{abstract}

Ключевые слова: мебелеподобные формы, мебель, генезис, первоначальное мебельное формообразование, функциональное предназначение, типология мебели. and Arts

Strilets Valeriy, Senior Lecturer, Department of Technology and Design, Kyiv National University of Culture

The emergence of furniture shaping in the prehistoric period

The purpose of the article is to identify trends in the initial shaping of furniture in the prehistoric period. The methodology in the study introduced the method of theoretical analysis, the creation of hypotheses based on known facts, with subsequent verification of the theoretical assumption of new facts. The scientific novelty consists in the hypothetically substantiated identification of trends in the emergence of furniture shaping and the actual confirmation of its dependence on the influence of the characteristics of the natural climatic environment, the anthropomorphic size of a person, and his religious ideas. Conclusions. Due to the hypothesis of the prehistoric process of the formation of furniture, and then furniture forms, the influence of local climatic characteristics on the construction of the ecologicalconstructive scheme of furniture has been proved. Also recorded a consistent effect on the initial shaping of furniture ergonomic and sacred factors; The dependence of the primitive shaping of furniture on the designated ecologicalconstructive scheme is highlighted.

Key words: furniture forms, furniture, genesis, initial furniture formation, functional purpose, furniture typology.

Історія формотворення меблів становить один із спеціальних розділів всесвітньої історії мистецтва й культури. Вона висвітлює процес формування естетики матеріального середовища та комфорту людини. Меблі служать для задоволення потреб людей, а потреби, водночас, призводять до змін іiі форми. Форма меблів указує на безпосереднє їх призначення; матеріал та оздоба - належність

(C) Стрілець В. Ф., 2019 
до суспільного класу; за деякими структурними особливостями приходять до висновку про час i місце виготовлення меблів [5, 8].

Актуальність теми дослідження. Спосіб теоретичного осягнення й осмислення питання формотворення меблів у доісторичний період очевидно лежить у площині його генезису. На сьогодні наукові джерела не дають повного розуміння цього явища, особливо такого важливого його сегменту як історично-первісне виникнення формотворення меблів, навіть повністю не проведене дослідницьке теоретико-гіпотетичне моделювання процесу первісного виникнення меблеподібних форм. Нерозуміння причин, ознак цього виникнення, що вже історично реалізувалося протягом тисячоліть в осмисленні типологічної форми меблів, і обумовило дослідження цієї локальної проблеми - первісного меблевого формотворення. А це, водночас, є науковою проблемою знань історичних витоків меблів як певної об'єктивної закономірності, що обумовила конкретне явище. Тому мета дослідження полягає в комплексному виявленні історичних причин та тенденцій первісного формотворення меблів.

Виклад основного матеріалу. При опрацюванні наукової літератури, з урахуванням специфіки процесу виникнення меблеподібних форм у первісної людини, автор статті визначив відповідні історичні часові рамки дослідження - доцивілізаційний період і час зародження стародавньої епохи перших цивілізацій - середина VI тисячоліття до нашої ери.

У сучасній Україні брак літератури та артефактів, що засвідчують генезис формотворення меблів, спричинив появу незначної кількості наукових публікацій у цьому напрямі - переважно історичних, освітніх та науково-технічних. Останні здебільшого описують матеріально-технологічну та технічну базу виготовлення меблів за останнє століття і по сьогодні. Загалом теоретичних матеріалів і джерел з формотворення меблів $є$ недостатньо для ведення дискусії 3 приводу певних проблем розвитку зазначеної галузі, особливо до епохи Середньовіччя [5, 9].

Збереглися технологічні описи процесу обробки матеріалів різними майстрами, натомість критичні статті про меблі в допромисловий ремісничий період нами не помічені, тому мова не йшла про виявлення тенденцій первісного розвитку формотворення меблів у цей час. Такий стан речей ускладнює наукові дослідження і спричиняє гіпотетичний підхід науковців до розкриття істинного стану історичного розвитку в означеній сфері, який на сьогодні в основному базується на археологічних артефактах, візуальних зображеннях, малюнках на предметах різного функціонального призначення, згадках про меблі в красному письменстві, листуванні, описах технологій обробки матеріалів старих майстрів. Чи не єдині цілком уцілілі оригінали-артефакти меблів до епохи Середньовіччя були знайдені в гробниці єгипетського фараона Тутанхамона та в деяких античних містах. У світових музеях меблі як фактологічний матеріал репрезентують оригінальні зразкиекспонати починаючи з епохи Середньовіччя.

Первісній еволюції меблів або дотичних до них найважливіших ознак розвитку певну увагу приділяли Ю. Борєв [1], М. Відейко [2], О. Грашин [3], Д. Кес [5], С. Мигаль [7], Н. Мухіна [10], R.Möller [11], Т. Форрест [12].

Д. Кес [5], С. Мигаль [7], Н. Мухіна [10] крім історії стилістики меблів гіпотетично дають інформацію про початкові меблеподібні форми у первісної людини. О. Грашин у праці «Короткий курс стильової еволюції меблів» звернув увагу на певну залежність стилістики меблевих об'єктів від стилістичних тенденцій тодішньої архітектури та інтер'єрів, розвитку технічних засобів й технологій виготовлення меблів у різні історичні епохи (або на їх відсутність) [3]. R. Möller [11], T. Форрест [12] систематизували періодизацію епох, стилів меблів, узагальнено виявили декоративні та прикладні особливості їх формотворення в різні періоди розвитку.

Слід зазначити, що кожен з вищевказаних авторів подає історичну картину одночасно в декількох головних, на їхню думку, країнах-лідерах з розвитку меблярства - у вигляді літературного опису або додатків - таблиць, що $\epsilon$ дуже цінним. Завдяки цьому досягається цілісна часова візуалізація зародження й розвитку конкретного меблевого стилю. Так формами, пропорціями, оздобленням меблів авторам частково вдалося відтворити історичну еволюцію художніх стилів. Наприклад, наслідування зразків античності проявилося в застосуванні архітектурних шаблонів, окремих деталей і цілих фрагментів [9, 22].

Водночас слід наголосити, що, не дивлячись на велику виконану роботу у сфері дослідження генезису меблів, вищеозначені автори не здійснили поглибленого аналізу проблем, пов'язаних 3 виникненням меблеподібних форм та формотворення меблів як явища. Окрім того, не були достатньо описані тенденції розвитку формотворення первісних меблів.

На сьогодні способами осягнення й теоретичного осмислення проблеми витоків меблів є: 1) вивчення археологічних даних та пам’яток найдавнішої культури; 2) вивчення етнографії народів, що 
перебувають на первісній стадії розвитку; 3) вивчення атавістичних форм у сучасній культурі; 4) осмислення даних давньої історії людства; 5) теоретична «екстраполяція в минуле» від відомих нам найпізніших феноменів та форм матеріальної культури; 6) стрибок через розрив інформації, теоретичне фантазування, створення гіпотез на основі відомих фактів, із подальшою перевіркою теоретичного припущення новими фактами; 7) зіставлення фактів та ідей, здобутих у вищезгаданий спосіб [1, 322].

Про еволюцію меблів доцивілізаційного періоду через обмаль фактичного матеріалу складно вести дискусії. Це спричинює гіпотетичний підхід науковців у питанні появи та розвитку меблеподібних форм. Археологія поки що не дає відповіді, як саме відбувався їх первісний розвиток, хоча фіксує меблеподібні утворення ще в IV тисячолітті до н. е.

На думку угорського науковця Д. Кеса, в епоху палеоліту людина ще не могла відірватися від землі, на якій сиділа і спала $[5,11]$, адже цьому сприяли кліматичні умови. Із цією думкою згодні й інші дослідники меблів [7;10].

В епоху палеоліту проживаючи в печері, людина робила стаціонарні вирізані меблеподібні форми-відмостки в материковій глині заглиблення в долівці для відпочинку, а також підставки під різні предмети, різні ніші в грунтових стінах $[7,31]$.

Зазначений етап розвитку створення меблеподібних форм, на думку автора статті, мотиваційно відповідав першочерговій необхідності життєвого циклу - сну, харчуванню, короткотривалому відпочинку, зберіганню та впорядкуванню речей. Наприклад, на історичній стадії приручення тварин людиною 3 метою покращення умов довготривалих переїздів вершників 3'являється така меблеподібна форма, як сідло.

Таким чином за функціональними ознаками виявляється перша тенденція виникнення формотворення меблів - спроби створити початкові функціональні меблеподібні структури, спроможні забезпечити першочергову необхідність життєдіяльності людини: сон, харчування, короткотривалий відпочинок, зберігання та впорядкування речей, транспортних зручних пристосувань.

Зі зміною кліматичних умов, у добу середнього та пізнього палеоліту, коли в Европі з'являлися льодовики, що принесли із собою холод, людина, щоб вижити, мусила одягатися та будувати житло. У такій, після печери первісній формі стаціонарного житла, як землянка, яка по суті була ямою, виритою у грунті й накритою зверху перетинкою для захисту від зовнішніх стихій (дощу, вітру, снігу тощо), на думку автора статті, був один суттєвий для виживання людини чинник збереження земляною масою в підземному просторі однієї стабільної температури з незначною різницею взимку і влітку (від $-1^{\circ}$ до $+7^{\circ} \mathrm{C}$ ), до того ж життєво важлива температура корегувалася багаттям. Але паралельно із цим чинником був суттєвий головний недолік підземного середовища вологість, що негативно впливала на здоров'я людини. Для зменшення впливу вологи, доцільно було піднімати помешкання до поверхні землі. Історичним прикладом можуть слугувати спочатку напівземлянки, а потім споруди з кісток тварин (мізинська культура), намети з дерев'яним каркасом i поверхневим напинанням його шкірами тварин.

Згодом у стаціонарних спорудах із дерева і глини рівень підлоги почали піднімати вище поверхні грунту (біля 40 см., які наповнювали глиною, що не пропускала вологу), де земляна волога вже суттєво відступала. Для такого житла можна було створювати менш об'ємні за габаритами, доцільні за матеріалами та раціональні меблеподібні форми, які пристосовували до розмірів та умов нового наземного помешкання.

У вигляді робочої гіпотези появи меблів як явища можна припустити, що в середині нового житлового простору, довкола якого були тундрові кліматичні умови, існувала інша небезпека для здоров'я людини - повітряний протяг на рівні долівки (близько 15 сантиметрів), що зберігся в людських помешканнях і донині, який був особливо небезпечний на материкових територіях, розташованих на далекій відстані від екватора (особливо в районах, де сходилися гарячі потоки екваторіальних вітрів і холодні потоки з полюсів земної кулі). На цій широті при зіткненні означених двох стихій утворювалося найбільше вологи, яка могла спричиняти сильні перепади температури. Через це в районах четвертого потепління, що межували 3 льодовиком (Вюрм), який вкрив декількакілометровим шаром Европу (окрім територій України і частково Іспанії), у помешканнях функціональні площини підіймали вище від долівки, переміщаючи весь домашній життєвий цикл на рівень приблизно від 40 до 80 см. над підлогою, що убезпечувало людину від протягу, а додатково від дрібних тварин-шкідників. Для цього створювали спочатку спеціальні монолітні, пізніше в помешканнях - кріпильні системні конструкції, що мали опори й несли на собі на різну висоту функціональні площини. Такою, на думку автора дослідження, є версія появи або утворення 
меблеподібних форм, а відтак - меблів, які можна було вже переставляти у внутрішньому середовищі будівель з метою додаткового захисту від протягу, використовуючи архітектурні природні перепони, наприклад, стіни чи печі, подалі від головного джерела протягу - вхідного прорізу будинку.

На цьому рівні висоти меблеподібні форми вже пристосовували до ергономічноантропометричних параметрів людини відповідно до комфортного для іiі здоров'я (функціонування органів) положення частин тіла й функціональних операцій у тому чи іншому життєвому циклі. I це $\epsilon$ другий чинник появи меблеподібних форм. Звідси можна зробити висновок, що меблі як на початку цивілізації, так і в наш час - це життєво необхідні предмети, у яких закладена функція збереження здоров'я людини. меблів:

Отже, на підставі цього висновку виявляються наступні тенденції виникнення формотворення

1) за природо-кліматичними ознаками - залежність форми, типу та матеріалів меблеподібних структур від природо-кліматичних умов життедіяльності людини: стінах);

a) печерне та підземне (землянка) житло в Палеоліті (відмостки у глині долівки, ніші у стійках);

б) наземне житло в післяльодовиковий період (меблеподібні функціональні площини на

2) за екологічними ознаками - прагнення створити об'ємно-просторові структури меблеподібних форм, здатні забезпечити захист здоров'я людини від загроз холодного протягу на рівні долівки (15 см) наземного помешкання;

3) за ергономічними ознаками - первісні врахування ергономічних розмірів людини в габаритних розмірах меблеподібних форм. Ця тенденція теж претендує на роль чинника появи формотворення меблів, але, на думку автора дослідження, вона $є$ похідною від версії шкоди для здоров'я людини протягу вологості в первісному помешканні.

У подальшому широкого використання набули дерев'яні меблеподібні форми: спочатку стаціонарні у вигляді інтер'єрного обладнання (піл, лава) [5, 33], [7, 69], пізніше - рухомі окремі функціональні одиниці, зручніші у зміні свого положення в інтер'єрі. Дерев'яні меблеподібні структури почали домінувати завдяки легкій обробці сировини, здатності деревини до фарбування, різьблення, комбінацій у подальшому розвиткові 3 металевими чи тканими виробами. Але найголовніше в перерахованих якостях дерева на думку автора статті $\epsilon$ те, що це матеріал рослинного походження, який разом із текстилем $є$ відновлюваним природою і найбільш лояльним до людського тіла, не чинить шкідливого чи алергійного впливу при контакті та характеризується стійким збереженням однієї температури комфортної та безпечної для людського тіла. Це є відмінною характеристикою від більшості матеріалів підземного походження (до прикладу, метали, каміння), які характеризуються змінною в залежності від зовнішніх впливів, перепадистою температурою, що призводить при постійному контакті до шкідливого впливу на людський організм.

Дерево й текстиль, порівняно з іншими матеріалами, швидше руйнуються протягом часу [1, 14], особливо на широті, де існує клімат з активною вологістю. Найдавніші вироби з дерева знайдено під час археологічних розкопок людських поселень, що відносяться до сколотських (скіфських) часів на теренах України - V - II ст. до н.е. [14]. У цей час відомі такі типи меблів, як столи, лави й ослони для спання. А відтак, палеолітичні меблеві вироби до нашого часу не збереглися. Тому версія походження меблів є на сьогодні не підкріпленою фактажем оригінальних зразків і залишається у вигляді гіпотези.

Із технічного погляду, первісна людина будувала примітивно, вона лише складала природний матеріал, але завдяки своїй винахідливості навчилася використовувати в якості складових частин меблеподібних структур вигнуту чи роздвоєну гілку дерева, в'язанку гілок $[5,16-17]$, рослинної прокладки, шкіри тварин тощо. Це визначення засвідчує тенденцію еволюції формотворення меблів цього періоду за технічними ознаками.

Крім того, загальновизнаною науковцями важливою тенденцією первісного формотворення меблів є відсутність межі між матеріальним та духовним світом: усі речі або сили були водночас $\mathrm{i}$ матеріальними, і духовними [6, 16-20]. Мистецтво, а можливо, і поява меблів, у первісному суспільстві - синкретичне явище, яке народжується з первісної магії (обладнання для ритуалів), пізніше зближується з релігією (церковні меблі), а в епоху Ренесансу постає осібно, секуляризується. Тож це $є$ третій чинник появи меблеподібних форм, але на думку автора дисертаційного дослідження, він $\epsilon$ похідним від версії шкоди для здоров'я людини протягу вологості в первісному помешканні та чинника ергономіки людини. 
Підсумовуючи сказане, приходимо до висновку, що у цьому випадку виявляється тенденція розвитку первісного формотворення меблів за естетичними ознаками - намагання світоглядні цінності спільноти первісних людей матеріалізувати в меблеподібних формах через художні засоби (символічну оздобу та пластику форми).

Коли уявлення про простір і форму, досвід і звичаї стали переважати над грубою доцільністю й виявилися спроможними виражати ідейний зміст, з'явилося усвідомлене художнє оформлення стиль [5].

Нагадаймо, що меблеподібні форми - це поєднання архітектурних споруд інтер'єрів житла 3 меблевими елементами, метою яких було утворення функціональних об'єктів для забезпечення першочергової необхідності життєвого циклу - сну, харчуванню, короткотривалому відпочинку, зберіганню та упорядкуванню речей. Іноді з часом ці меблеві елементи поступово перетворювалися типологічно на подобу меблів, але ще не рухомих й прикріплених до стін або до підлоги. Меблі ж належать до рухомого, мобільного майна людини. Їх можна переміщати і стаціонарно встановлювати на певний час по всьому житловому інтер'єру будинку.

Перехід меблеподібних форм до меблів можливо остаточно оформився 3 настанням цивілізаційних культур осілого способу життя людей. Але повного переходу до меблів так і не сталося. Обидві означені формації існують паралельно й по сьогодні, хоча з більшою перевагою у бік меблів.

Складність виявлення інформації про ознаки еволюції стародавніх меблів полягає в тому, що мало збереглося їх фактичних оригінальних зразків $[5,10]$, які б засвідчували основні тенденції розвитку формотворення меблів. Більшість джерел, що вказують на існування меблів у період перших цивілізацій людства, беруть за основу сюжетні малюнки з їх зображенням та археологічні музейні експонати: рельєфи, барельєфи [5], статуетки [5, 45], кам'яні скульптури [5, 7], графічні зображення на картинах $[5,7]$, стінах (фрески) [5, 7], вазах [7], залучалися також письмові спогади про меблі при характеристиці народностей $[5,7]$. Винятком із цього ряду є відновлені археологами 3 фрагментів меблі, віднайдені в гробниці цариці Хетепхерес [13], ціла неушкоджена колекція меблів із поховання фараона Тутанхамона в Єгипті [5] і деяких зразків з розкопок міста Помпеї в Італії.

Можна припустити, що коли людина, перейшовши від кочового до осілого способу життя, почала освоювати метали: на межі IV - III тисячоліть до н. е. - бронзу, а в кінці II тисячоліття до н. е. - залізо, - відтоді були створені передумови для вдосконалення інструментарію, методів будівництва житла, а відтак - розвитку формотворення меблів (бронзу знайдено серед решток будівель на палях).

В археологічному музеї м. Одеси (Україна) зберігається глиняна сидяча фігурка жінки в кріслі, що є пам'яткою трипільської культури (сер. V-III тис. до н. е.) й символізує богиню-матір, родоначальницю, об'єкт поклоніння для стародавніх землеробів $[10,37]$. У ті часи скульптурні твори виконувалися переважно із дерева. Мистецькими якостями вони могли впливати на кам'яну чи керамічну пластику, однак у зв'язку з нетривкістю матеріалу просто не збереглися.

Житла трипільців були наземними, мали каркасно-стовпову конструкцію. Стіни робили 3 дерева або плели з лози, а потім - обмазували глиною з домішками полови (технологія збереглася у традиційній українській хаті-мазанці).

Будівлі були великого розміру, значна їх частина була двоповерховою 3 чотирисхилими дахами та вікнами. Підлога намащувалася глиною, обпалювалася. 3 решток обпаленої глини 3 різноманітними відбитками (у результаті пожеж, бо трипільці раз в 50-70 років переносили поселення в нові місця, а старі - спалювали) стало відомо, що деякі меблеподібні форми робилися 3 глини лежанки, лави, столи-підвищення, жертовники. Але паралельно вже існували і меблі. Завдяки пам'яткам дрібної керамічної пластики племен культури Трипілля, нам відомі такі меблеві типи цього періоду, як трон, стілець [2], лава, лежанка, стіл $[4,7]$. У житлах трипільців виявлена подоба скрині-жертовника (поселення Окопи, Подністров'я) [9, 252-253], що вказує на можливість існування в ті часи меблів-ємностей. Крім того, є трони з силуетною оздобою його спинки антропоморфними й зооморфними силуетами (поселення Ріпниця в околиці міста Ржищева Київської області) [9, 113], що фактично вказує на тенденцію первісного розвитку художньо-декоративних технік (ажурно-силуетної групи) в меблях цього періоду. 


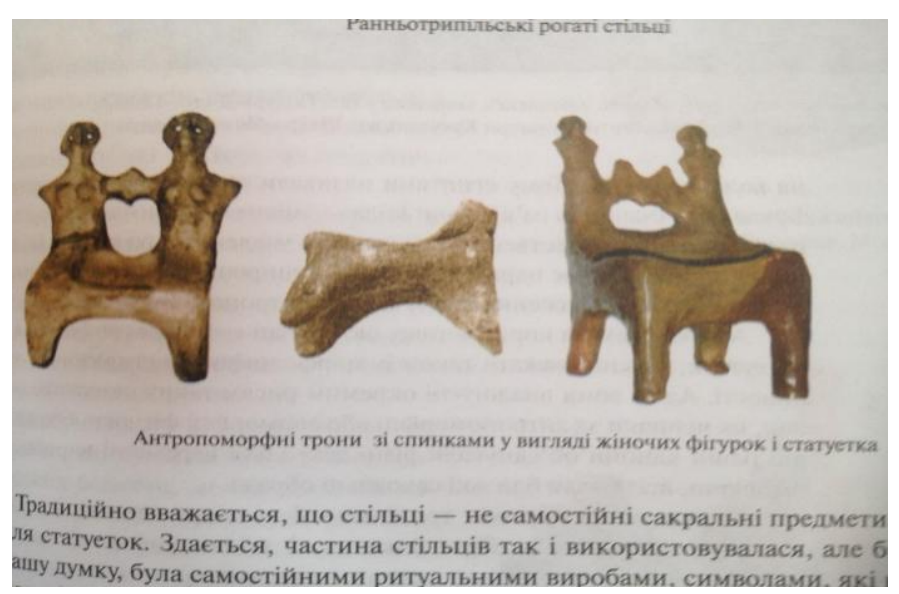

Рис. 1. Мініатюрні керамічні моделі антропоморфних тронів трипільської культури (за матеріалами: Бурдо Н. Сакральний світ трипільської цивілізації. К.: Наш час, 2008. 296 с.).

У формах усіх виявлених археологами глиняних зразків меблевих типів Трипільської культури виразно проглядаються тенденції розвитку формотворення меблів за природокліматичними ознаками наземного житла, за екологічними ознаками (захист здоров'я людини від загроз холодного протягу на рівні долівки - 15 см. наземного помешкання). Особливо у меблевих типах проглядаються тенденції розвитку за ергономічними ознаками (первісні врахування ергономічних розмірів людини в габаритах меблевих форм) у бік комфортних пристосувань. Наприклад, сидіння трону і стільця за функціональним призначенням не лише підняте на безпечну висоту, але й за його структурною схемою програмується відключення напруги ніг, забезпечення безперешкодного кровообігу в людському організмі. Спинка, що загинається від сидіння, програмує часткове зняття напруги торсу людини. Тож дані моделі $є$ осмисленими, вони створені для відключення непотрібних для роботи на якийсь час напружень людського тіла та його тимчасового відпочинку. За цією схемою напруженими залишаються лише включені в роботу руки й голова людини. У зразках, де відсутня спинка, включається робота торсу. Підлокітників й підголовників за наявними археологічними трипільськими глиняними зразками меблевих типів ще не було. Вони з'явилися в часи Шумерсько-Вавілонської цивілізацій. Отже меблеве формотворення розвивається у напрямі регуляторів фізичних функціональних напружень, а відтак забезпечення раціонального й безпечного положення людського тіла з метою досягнення комфорту і якості у виконанні практичних чи корисних функцій праці та відпочинку, упорядкування й зберігання предметів особистого користування й спеціального призначення, безпечного ергономічного розташування функціональних площин.

Тому в трипільській культурі типологічно за ознаками функціонального призначення 3'являються меблі для сидіння, для лежання, ємності, функціональні площини, комбіновані меблі (поєднання столу, скрині і вівтаря).

Слід наголосити й констатувати, що це вже були не меблеподібні стаціонарні структури обладнання житла, а справжні меблі («mobilis» у перекладі з латини означає «рухомий»).

Глиняні зразки трипільських меблів вказують на тенденцію розвитку формотворчих технік утилітарної галузі декоративного мистецтва і претендують на роль архетипів - первинних початкових форм меблевих виробів як за історико-культурними, функціонально-типологічними, технічними, так $\mathrm{i}$ естетичними ознаками.

Можливі інші типи меблів, поки що не виявлені в археологічних розкопках, хоча трипільці проіснували декілька тисячоліть, тому відповіді - за майбутніми археологічними відкриттями.

3 розвитком цивілізації, коли спосіб виготовлення меблів набув певної логічної послідовності, меблі набули ознак комфорту, зумовлених, насамперед, прагненням до пропорційності з фізичними параметрами людини та іï житла.

Наукова новизна цієї статті полягає у виявленні тенденцій виникнення меблеподібних форм та фактичним підтвердженням залежності його функціонального формотворення від впливу середовища життєдіяльності людини, iї антропоморфних розмірів, культових уявлень, із подальшою перевіркою теоретичного припущення фактами побудови первісних форм меблів у трипільській культурі. 
Висновки. Завдяки гіпотезі доісторичного процесу утворення меблеподібних, а відтак меблевих форм, доведено вплив локальних кліматичних характеристик на побудову екологоконструктивної схеми меблів. Також зафіксований послідовний вплив на первісне формотворення меблів ергономічного й сакрального чинників; висвітлено залежність первісного формотворення меблів від означеної еколого-конструктивної схеми.

\section{Jimepamypa}

1. Борев Ю. Эстетика. Москва: Политиздат, 1988. 496 с.

2. Відейко М. Ю. Світ Трипілля. Київ: Laurus, 2014. 63 с. 2007. $416 \mathrm{c}$.

3. Грашин А. А. Краткий курс стилевой эволюции мебели : учеб. пособие. Москва: Архитектура-С,

4. Губерначук С. Карби трипільської доби. Київ: Четверта хвиля, 2008. 232 с.

5. Кес Д. Стили мебели. - Будапешт: Издательство Академии наук Венгрии, 1981. - 269 с.

6. Ліндсей Д. Коротка історія культури. Ч. 1. Київ: Мистецтво, 1995. 234 с.

7. Мигаль, С. П. Проектування меблів : навч. посібник. Львів : Світ, 1999. 216 с.

8. Мигаль С., Бугаєнко Я., Любченко В. Атрибуція меблів : навч. посібник. Львів: ЛЛТИ, 1991. 36 с.

9. Мицик В. За законом світового ладу. К: МАУП, 2007. 327 с.

10. Мухіна Н. Історія меблів. Епохи та стилі. К.: КНУКІМ, 2003. 284 с.

11. Möller R. Mobel. Munchen - Berlin: Deutscher Kunstverlag, 2005. 165.

12. Форрест Т. Антикварная мебель / [перевод с англ. М. Катковой]. М: Эгмонт Россия ЛТД, 1997.160 с.

13. Чизхолм Д., Миллард Э. Ранние цивилизации / [перевод с англ. А.M. Golova].Москва: Росмэн, 1999.

$96 \mathrm{c.}$

14. Шевченко Є. Народна деревообробка в Україні: [словник народної термінології]. Київ: Артанія, 1997. 312 c. : іл.

\section{References}

1 Borev Y. (1982). Estetica. Moskva: Politizdat. [in Russian].

2 Vidiko M. (2014). Svit Trypillia. Kyiv: Laurus. [in Ukrainian].

3 Grashin A. (2007). Kratkiy kurs stilevoy evolyutsii mebeli : ucheb. posobie. Moskva: Arhitektura-S. [in Russian].

4 Hubernachuk S. (2008). Karby trypilskoi doby. Kyiv: Chetverta hvilia. [in Ukrainian].

5 Kes D. (1981). Stili mebeli. Budapesht: Izdatelstvo Akademii nauk Vengrii. [in Hungarian].

6 Lindsay D. (1995). Korotka istoriia kultury. Ch. 1. Kyiv: Mistetstvo. [in Ukrainian].

7 Migal S. P. (1999). Proektuvannia mebliv : navch. posibnyk. Lviv: Svit. [in Ukrainian]. [in Ukrainian].

8 Migal S. P., Bugaenko Y.P., Lyubchenko V.F. (1991). Atrybutsiia mebliv : navch. posibnyk. Lviv: LLTI.

9 Mitzik V. (2007). Za zakonom svitovoho ladu. Kyiv: Mizhrehionalna akademiia upravlinnia personalom. [in Ukrainian].

10 Mukhina N. (2003). Istoriia mebliv. Epokhy ta styli. Kyiv: KNUCIM [in Ukrainian].

11 Möller R. Mobel. Munchen, - Berlin: Deutscher Kunstverlag, 2005. - 165p.

12 Forrest T. (1997). Antikvarnaya mebel / [translation from english M. Katkova]. Moscwa: Egmont Rossia LTD [in Russian].

13 Chisholme D., Millard E. (1999). Rannie tsivilizatsii [translation from english A.M. Golova]. Moscwa: Rosmen [in Russian].

14 Shevchenko E. (1997). Narodna derevoobrobka v Ukraini: [dictionary of national terminology]. Kyiv: Artania [in Ukrainian]. 